\title{
IAMJ
}

INTERNATIONAL

AYURVEDIC

MEDICAL JOURNAL

do) 2 ( )

\section{A SINGLE CASE STUDY TO EVALUATE THE EFFECTIVENESS OF AYURVEDA TREATMENT PROTOCOL USING EUPHORBIA LATEX IN UTSANGINI W.S.R TO CHALAZION}

\author{
Swarna Ranjita Bhat ${ }^{1^{*}}$, Nirmal Krishnan $\mathbf{R}^{2}$, Ahalya $S^{3}$ \\ ${ }^{1 *, 2}$ PG Scholar Department of Shalakya Tantra, ${ }^{3}$ Principal, \\ Government Ayurveda medical College, Bengaluru, Karnataka, India
}

Corresponding Author: dr.swarnaranjita@gmail.com

https://doi.org/10.46607/iamj3409112021

(Published Online: November 2021)

Open Access

(C) International Ayurvedic Medical Journal, India

Article Received: 17/10//2021 - Peer Reviewed: 30/10/2021 - Accepted for Publication: 31/10/2021

Check for updates

\begin{abstract}
Introduction: - Chalazion is also known as a tarsal 'cyst' or meibomian 'cyst'. This is not a cyst but a chronic inflammatory granuloma of a meibomian gland. Chalazia are often multiple, occurring in crops. The contemporary treatment modalities include eyelid hygiene with hot compresses, topical antibiotic ointment and also steroid injections. Most lesions usually necessitate more invasive procedures. If the chalazion does not resolve, it should be incised and curetted. its management is difficult, due to its high recurrence rate and chronicity. It is correlated to Utsangini in Ayurveda. Ayurveda can provide safe and cost-effective results in Utsangini with both Shodhana and Shamana Chikitsa. Materials and Methods: -A case of Chalazion successfully treated with local application of dugdhika ksheera and bidalaka with mukkadi churna along with a few internal medicines is recorded here. Result: The subject had shown good improvement
\end{abstract}

Conclusion: Latex of euphorbia latex has a good effect on the management of Utsangini.

Keywords: Chalazion, Utsangini Bidalaka, Dugdhika Ksheera, Mukkadi Churna.

\section{INTRODUCTION}

Chalazion is a chronic lipo-granulomatous inflammation of the meibomian or Zeis glands, caused by cystic retention of material in the sebaceous glands. It is one of the commonest eyelid disorders of all age groups, and usually, presents with inflammation and irritation of the eyelid and ocular surface. Although it may be a self-limited disease, its management can be difficult for both the ophthalmologists and the patients, due to its high recurrence rate and chronicity. The treatment modalities include eyelid hygiene 
with hot compresses, topical antibiotic ointment, and systemic tetracycline in cases with acne rosacea.

However, most lesions usually necessitate more invasive procedures like steroid injections or incision and curettage surgery.

A chalazion, or meibomian cyst, is a focus of granulomatous inflammation within the eyelid. It arises from retained meibomian secretions. It is benign and often self-limiting. It can occur in all age groups and is common in primary care.

Patients report a slowly enlarging lump with some variability in size on a day-to-day basis. Ask about skin conditions that predispose to meibomian gland dysfunction - acne rosacea and seborrhoeic dermatitis. Larger chalazions may be associated with visual symptoms. Ask about blurry vision from induced astigmatism or awareness of visual field obstruction from mechanical ptosis.

It is correlated to Utsangini in Ayurveda. Utsangini is explained under Vartmagatha Rogas by both Sushrutha and Vagbhata. It is a Tridoshaja Sadhya Vyadhi according to Sushrutha. ${ }^{1}$ But according to Vagbhata it is a Raktaja Sadhya Vyadhi. Both Shodhana and Shamana Chikitsa is mentioned in the treatment of Utsangini. In contemporary science, treatments are intralesional corticosteroid injection and surgical drainage. Ayurveda can provide safe and cost-effective results in Chalazion. Here a case of Chalazion successfully treated with Ayurvedic management is recorded.

\section{CASE STUDY}

A normal man of 32 years of age noticed an Itching sensation in the right lower lid of the eye associated with small swelling and redness, swelling gradually increased in size. And later suffered from watering from the eye, hence he consulted Government Ayurveda Medical College Outpatient Department for the same and started Treatment.

\section{Hetu}

The patient used to consume very spicy and deepfried food and used to work more in front of computers and mobile screens. These factors might have influenced the pathology.

\section{General Examination}
1. Condition - General
2. RS - NAD
3. CVS - S1S2 - NAD. No added Sound
4. CNS - NAD
5. $\mathrm{P} / \mathrm{A}$ - SOFT
6. BP $-120 / 80 \mathrm{mmHg}$
7. Pulse $-72 / \mathrm{min}$

Prakruti - vata pitta

Saara-Mamsa

\section{Darshana}

- Agni - Sama

- Srotas-Raktavaha

- Nidana - Ushna Ahara, ati Sookshma darshana, prabhavatam darshana.

\section{Local Examination}

\begin{tabular}{|l|l|l|}
\hline Eyelid & NAD & Marked swelling in the left lower lid \\
\hline Palpebral conjunctiva & NAD & Congestion marked swelling with minute opening \\
\hline Bulbar conjunctiva & NAD & NAD \\
\hline Cornea & Clear & Clear \\
\hline Pupil & RRR & RRR \\
\hline Lens & Phakic & Phakic \\
\hline
\end{tabular}

\section{Treatment}

\section{$1^{\text {st }}$ sitting}

Dugdhika ksheera (Euphorbia hirta)- applied over utsangini- 1 week

Triphala guggulu-2 bd. After food -2 weeks Avipattikara churna-1tsp at night with milk - 2 weeks

$2^{\text {nd }}$ sitting

Mukkadi churna bidalaka-1week
Dhanyaka Hima Seka-1week

Mahamanjisthadi Kashaya-20ml-0-20ml before food

\section{DISCUSSION}

The present case was acute so only nitya virechana with avipattikara churna was given. Symptoms and Prakruthi of the patient were more of Pitta so both 
Pithahara and Raktha Prasadhaka line of treatment was adopted.

The stem sap of dugdhika is used in stye, the latex of dugdhika is applied on lower eyelids to cure eyesores. Its rasa is tikta and katu, vipaka is katu, and veerya is ushna. Mainly because of its Kshara property it's useful in the removal of Chalazion. ${ }^{2}$ Netra Parisheka is done with Dhanyaka hima. ${ }^{3}$ Netra Parisheka is one among the Kriya Kalpas mentioned for Netra Roga. This local therapy acts by resolving the obstruction of channels, removing micro-organisms and enhancing local blood circulation which is helpful for quick and easy absorption of drugs. Moreover, these drugs have Chakshushya, anti-inflammatory and antimicrobial properties. Its rasa is kashaya, tikta. It is laghu and snigdha guna yukta and is ushna virya but vipaka is madhura. It acts as tridoshahara. Samana. Mukkadi churna mentioned in sahasrayoga is used for bidalaka which is composed of many sheethaveerya drugs including Chandana, Usheera, Sariva etc. helps to reduce the local heat and inflammatory reactions. ${ }^{4}$ Internal Oushadhi selected was Triphala Guggulu is an Ayurvedic formulation that provides the combined effects of Triphala and Guggulu. Triphala brings detoxifying and laxative properties, while Guggulu provides anti-inflammatory properties. Based on these properties, it helped in relieving symptoms of Chalazion.

\section{CONCLUSION}

This case study reveals that patients with chalazion can gain significant results through Ayurveda management. Nityavirechana helps in clearing the Sroto Avarodha. Dhanyaka Hima Seka helps to relieve congestion and itching sensation and Bidalaka with Mukkadi churna reduces the local inflammation. Internal medications like Triphala Guggulu also help to subside inflammatory changes.

\section{REFERENCES}

1. Sushruta, sushruta samhita, updravik addhyay Uttar tantra 3/9-10, Nibandh Samgrah commentary by Shri Dalhanacharya Edited by vaidya yadavaji Trikamji Acharya; Chaukhambha surbharati prakrashan, Varanasi, Reprint edition-2003.

2. Dr Pradeep Kumar, A review article on medicinal importance of dugdhika, wjpmr, 2021,7(10), 95 - 98
3. Prof. K. R. Sreekantha Murthy, Sarngadhara Samhita, Uttara Khanda, 4/7, Chaukhambha orientalia Varanasi, Reprint Edition 2012, Page No.80.

4. K. V Krishnan Vaidyan and S. Gopala Pillai, Sahasrayogam, Sujanapriya Commentary, Netrarogadhikara, Vidyarambham Publishers, $32^{\text {nd }}$ edition, October- 2013, Page No.381

\section{Source of Support: Nil Conflict of Interest: None Declared}

How to cite this URL: Swarna Ranjita Bhat et al: A Single Case Study To Evaluate The Effectiveness Of Ayurveda Treatment Protocol Using Euphorbia Latex In Utsangini W.S.R To Chalazion. International Ayurvedic Medical Journal \{online\} 2021 \{cited November 2021\} Available from: http://www.iamj.in/posts/images/upload/2859_2861.pdf 